\title{
MODEL SISTEM PERADILAN TERHADAP ANAK YANG BERHADAPAN DENGAN HUKUM DENGAN PENDEKATAN DIVERSI DAN RESTORATIF JUSTICE STUDI KASUS DI BAPAS KOTA SURAKARTA
}

\author{
Asika Mahargini \\ Magister Ilmu Hukum \\ Universitas Muhammadiyah Surakarta
}

\begin{abstract}
Absract
$S$ on is a mandate from God Almighty, the DI in her inherent dignity as human beings. Philosophically, children are the future of the nation, and as a generation of struggle. A troubled child, means to be a problem of the nation. This study aims to identify and provide insight about the duties and authorities of Correctional Center (CC), the important role of the cooperation between CC with related institutions, and offer a model of cooperation pattern between CC with related institution, associated with the handling of children dealing with the law (CDL) in Surakarta, inside diversion and restorative justice system. This is a qualitative research, with a sociological juridical approach. Source of data derived from secondary data and primary data. Method of data collection using observation, interviews, and document study. Method of data analysis using several stages, starting from inventory and grouping the data, unto data analysis and making conclusions.The conclusions of this study, among others 1) Surakarta CC role in handling CDL, because the Community Supervisor (CS) has three roles in the law enforcement process, namely, Pre-Adjudication, Adjudication, and Post Adjudication, 2) Surakarta CC through CS carries out its functions since the suspected child being arrested by the police and reported for examination, unto decided by the judge, and 3) run consistently the Articles 7 and 8 of Statute No. 11 Year 2012 about the Children Criminal Justice System, in order to be synergy among the legal apparatus in overcoming $C D L$, aiming on the implementation of psychological recovery, security, protection of the child's future, not having discriminated in the community, and children get restorative justice.
\end{abstract}

Keywords: Diversion, Restorative Justice, Children Dealing with the Law

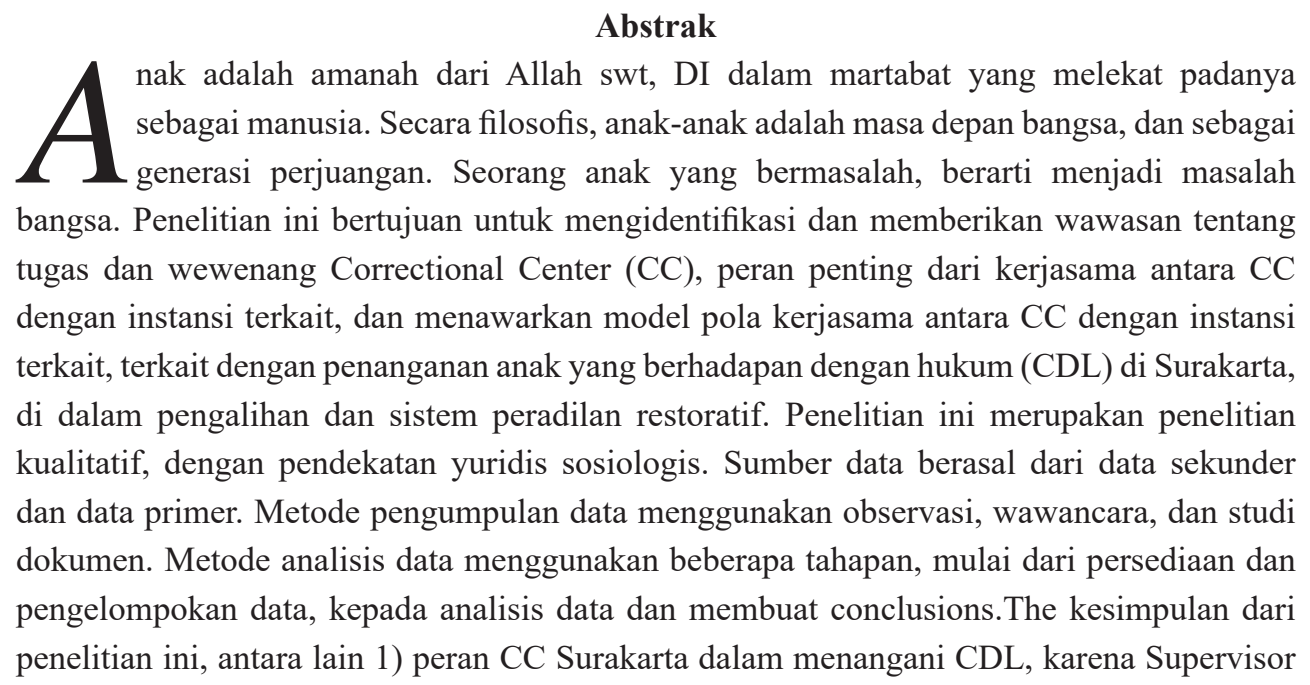


Community (CS) memiliki tiga peran dalam proses penegakan hukum, yaitu, Pre-Ajudikasi, Ajudikasi, dan Pasca Ajudikasi, 2) CC Surakarta melalui CS menjalankan fungsinya sejak anak yang diduga ditangkap oleh polisi dan melaporkan untuk pemeriksaan, kepada diputuskan oleh hakim, dan 3 ) menjalankan secara konsisten Anggaran 7 dan 8 dari UU No. 11 Tahun 2012 tentang anak Criminal Justice System, agar sinergi antara aparat hukum dalam mengatasi CDL, bertujuan pada pelaksanaan pemulihan psikologis, keamanan, perlindungan masa depan anak, tidak memiliki diskriminasi di masyarakat, dan anak-anak mendapatkan keadilan restoratif.

\section{Kata kunci: Diversion, Keadilan Restoratif, Anak Berurusan dengan Hukum}

\section{Pendahuluan}

Anak merupakan amanah dari Tuhan Yang Maha Esa, yang di dalam dirinya melekat harkat dan martabat sebagai manusia seutuhnya. Secara filosofis, anak merupakan masa depan bangsa, dan sebagai generasi penerus perjuangan. Seorang anak yang bermasalah, berarti menjadi masalah bangsa. Oleh karena itu, kepentingan terbaik bagi anak harus menjadi pilihan yang diutamakan dalam menangani anak yang bermasalah atau berkonflik dengan hukum. Anak sebagai bagian dari generasi muda merupakan mata rantai awal yang penting dan menentukan dalam upaya menyiapkan dan mewujudkan masa depan bangsa dan negara. Namun, apabila anak kurang mendapatkan perhatian dari lingkungan terdekatnya maka mudah baginya untuk melakukan perbuatan yang menyimpang dari norma hukum yang berlaku di masyarakat. Dimulai dari perbuatan sebatas kenakalan remaja hingga akhirnya menjurus pada perbuatan kriminal yang membutuhkan penanganan hukum secara serius, khususnya perlindungan hakhak anak dalam proses peradilan pidana.

Padahal setiap anak mempunyai harkat dan martabat yang patut dijunjung tinggi dan setiap anak yang terlahir harus mendapatkan hak-haknya tanpa harus meminta. Hal ini sesuai dengan ketentuan Konvensi Hak Anak (Convention on the Rights of the Child) yang diratifikasi oleh pemerintah Indonesia melalui Keputusan Presiden Nomor 36 Tahun 1990, kemudian juga dituangkan dalam Undang-Undang Nomor 4 Tahun 1979 tentang Kesejahteraan Anak dan Undang-Undang Nomor 23 Tahun 2002 tentang Perlindungan Anak, yang mengemukakan prinsip-prinsip umum perlindungan anak, yaitu non-diskriminasi, kepentingan terbaik bagi anak, kelangsungan hidup dan tumbuh kembang, dan menghargai partisipasi anak.

Melihat prinsip-prinsip tentang perlindungan anak terutama prinsip mengutamakan kepentingan terbaik bagi anak maka diperlukan proses penyelesaian perkara anak diluar mekanisme pidana atau biasa disebut diversi, karena lembaga pemasyarakatan (LP-Lapas) bukanlah jalan untuk menyelesaikan permasalahan anak, dan justru dalam LP rawan terjadi pelanggaran-pelanggaran terhadap hak anak. Oleh karena itu, diversi, khususnya melalui konsep restorative justice, menjadi suatu pertimbangan yang sangat penting dalam menyelesaikan perkara pidana yang dilakukan oleh anak.

Sistem Peradilan Pidana Anak dalam Juvenile Justice System adalah segala unsur sistem peradilan pidana yang terkait di dalam penanganan kasus-kasus kenakalan anak. Pertama, polisi sebagai institusi formal ketika anak nakal pertama kali bersentuhan dengan sistem peradilan, yang juga akan menentukan apakah anak akan dibebaskan atau diproses lebih lanjut. Kedua, jaksa dan lembaga pembebasan bersyarat yang juga akan menentukan apakah anak akan dibebaskan atau diproses ke pengadilan anak. Ketiga, Pengadilan Anak, tahapan ketika anak akan ditempatkan dalam pilihan-pilihan, mulai dari dibebaskan sampai dimasukkan dalam institusi penghukuman. Dan keempat adalah Balai Pemasyarakatan (Bapas) tersebut bergerak sejak tahap penyelidikan, penyidikan hingga tahap pembimbingan setelah menjalani pidana. Sehubungan dengan hal ini, Muladi yang menyatakan bahwa criminal justice system memiliki 
tujuan untuk: a) resosialisasi dan rehabilitasi pelaku tindak pidana, b) pemberantasan kejahatan, dan c) dan untuk mencapai kesejahteraan sosial. ${ }^{1}$

Berangkat dari pemikiran ini, maka tujuan sistem peradilan pidana anak terpadu lebih ditekankan kepada upaya pertama (resosialiasi dan rehabilitasi) dan ketiga (kesejahteraan sosial). Namun upaya yang lain di luar mekanisme pidana atau peradilan juga dapat dilakukan dengan beberapa metode, di antaranya metode Diversi dan Restorative Justice. Program Diversi dapat menjadi bentuk Restoratif Justice jika: ${ }^{2}$

1. Mendorong anak untuk bertanggung jawab atas perbuatannya;

2. Memberikan kesempatan bagi anak untuk mengganti kesalahan yang dilakukan dengan berbuat kebaikan bagi si korban;

3. Memberikan kesempatan bagi si korban untuk ikut serta dalam proses;

4. Memberikan kesempatan bagi anak untuk dapat mempertahankan hubungan dengan keluarga.

5. Memberikan kesempatan bagi rekonsiliasi dan penyembuhan dalam masyarakat yang dirugikan oleh tindak pidana.

Dari segi filosofi yang mendasari dalam undang-undang peradilan anak adalah karena anak belum dapat memahami apa yang dilakukannya serta mengedepankan kepentingan terbaik bagi anak (The Best Interest for the child) dan sesuai Konvensi Hak Anak (Convention On The Rights Of The Child) 1990 yang diratifikasi oleh Indonesia selaku anggota United Nations (PBB) melalui Keppres No. 36 tahun 1990 menyatakan bahwa pidana merupakan upaya terakhir (Ultimum Remedium), karena anak adalah aset bangsa dan generasi penerus. Konsep diversi juga mempertimbangkan kepentingan korban, kepatutan di dalam masyarakat, umur anak (minimal 12 tahun) dan pertimbangan pihak lain, dalam hal ini Balai Pemasyarakatan. Keputusan Diversi dapat berupa penggantian dengan ganti rugi, penyerahan kembali ke orang tua, kerja sosial selama 3 bulan, dan pelayanan masyarakat. ${ }^{3}$

Keberadaan diversi di Indonesia telah diakui melalui Undang -Undang Sistem Peradilan Pidana Anak (UU SPPA) yang disahkan pada tanggal 30 Juli 2012 dan mulai berlaku efektif 2 (dua) tahun kemudian. Pasal 7 ayat (1) UU SPPA menyatakan bahwa "Pada tingkatan penyidikan, penuntutan dan pemeriksaan perkara anak di pengadilan negeri wajib diupayakan diversi”. Syarat atau kriteria tindak pidana yang dapat dilakukan diversi adalah sebagaimana dijelaskan dalam Pasal 7 ayat (2) UU SPPA. ${ }^{4}$

Selama ini Perlakuan terhadap anak yang di duga melakukan tindak pidana seringkali bersifat sangat represif. Proses peradilan terhadap anak seringkali kehilangan makna esensinya sebagai mekanisme yang harus berakhir dengan upaya untuk melindungi kepentingan terbaik bagi anak (the best interest of child). Proses peradilan pidana anak seringkali menampilkan dirinya sebagai mekanisme yang hanya berorientasi pada penegakan hukum secara formal dan tidak berorientasi pada kepentingan anak. ${ }^{5}$

Perlakuan-perlakuan yang cenderung membekaskan stigma atas diri anak lebih mengedepan dibandingkan perlakuan aparat penegak hukum yang mencerminkan perlindungan

1 Anjar Nawan, Konsep Diversi dan Restoratif Justice, dalam https://www.anjarnawanyep.com/konsep-diversi-dan-restorative-justice/, diakses tgl 20 November 2014 jam 15.15

$2 \quad$ Ibid

3 Martina, Efektifkah Konsep Diversi dan Keadilan Restoratif pada Sistem Peradilan Anak di Indonesia?, dalam http:/hukum.kompasiana.com/2012/08/21/efektifkah-konsep-diversi-dan-keadilan-restoratif-padasistem-peradilan-anak-di-indonesia-487685.html, diakses tgl 20 November 2014 jam 15.15

4 Achmad Rotami, dalam http://hukum.ub.ac.id/wp-content/uploads/2014/01/JURNAL-revisi-Achmad-Ratomi.pdf, diakses tgl 20 November 2014 jam 15.30

5 Koesno Adi, Kebijakan Kriminal dalam Sistem Peradilan Pidana yang Berorientasi pada Kepentingan Terbaik Bagi Anak, Pidato Pengukuhan Jabatan Guru Besar dalam bidang Ilmu Hukum Pada Fakultas Hukum Universitas Brawijaya Malang, 2009. Hal. 6 
hak-hak anak yang melakukan tindak pidana. Anak yang terlibat dalam proses peradilan pidana memperoleh perlakuan yang buruk bahkan dalam beberapa hal telah diperlakukan lebih buruk bila dibandingkan dengan orang dewasa yang berada dalam situasi yang sama. Mayoritas dari anak yang melakukan tindak pidana mengalami tindak kekerasan selama dalam proses peradilan pidana. ${ }^{6}$

Lebih dari 4.000 anak Indonesia diajukan ke pengadilan setiap tahunnya atas kejahatan ringan, seperti pencurian Pada umumnya tidak mendapatkan dukungan, baik dari pengacara maupun dinas sosial. Dengan demikian, tidak mengejutkan jika sembilan dari sepuluh anaknnya dijebloskan ke penjara atau rumah tahanan. Sebagai contoh sepanjang tahun 2000 tercatat dalam statistik kriminal kepolisian terdapat lebih dari 11.344 anak yang disangka sebagai pelaku tindak pidana. Pada bulan Januari hingga Mei 2002 ditemukan 4.325 tahanan anak di rumah tahanan dan lembaga pemasyarakatan di seluruh Indonesia. Jumlah tersebut belum termasuk anak anak yang ditahan di kantor polisi (Polsek, Polres, Polda, Mabes). Kemudian pada tahun yang sama, tercatat 9.456 anak yang berstatus anak didik (anak sipil, anak negara, dan anak pidana) tersebar di seluruh Rutan dan Lembaga Pemasyarakatan (LP) untuk orang dewasa. Kondisi ini sangat memprihatinkan, karena banyak anak yang harus berhadapan dengan sistem peradilan dan mereka ditempatkan di tempat penahanan dan pemenjaraan bersama orang dewasa sehingga mereka rawan mengalami tindak kekerasan. ${ }^{7}$

Fenomena di atas menunjukkan, bahwa penanganan terhadap anak sebagai pelaku tindak pidana oleh aparat penegak hukum melalui proses peradilan yang selama ini berlangsung, cenderung merugikan masa depan anak. Keadaan tersebut bukan saja sangat memprihatinkan, namun sangat mengkhawatirkan, karena menggambarkan bahwa penanganan pada anak yang diduga melakukan tindak pidana belum benar-benar mencerminkan perlindungan anak. ${ }^{8}$ Ditambah lagi penerapan metode kurungan yang selama ini dilakukan tidak selalu berhasil memberi efek jera pada kasus anak-anak. Dalam diri anak tersebut belum ada kesadaran akan akibat perbuatannya.

Penanganan perkara anak dalam UU SPPA memberi penguatan terhadap peran pemasyarakatan, berada dalam keseluruhan penanganan anak yang berkonflik dengan hukum, dalam kaitan dengan pembinaan, pembimbingan, pengawasan dan/atau pendampingan. Di sinilah, maka, peran Balai Pemasyarakatan (BAPAS), Rumah Tahanan Negara (RUTAN) yang akan dibentuk menjadi Lembaga Penempatan Anak Sementara (LPAS) dan Lembaga Pemasyarakatan Anak Negara (LPAN) yang nanti akan berubah menjadi Lembaga Pembinaan Khusus Anak (LPKA), sebagai Unit Pelaksana Teknis Pemasyarakatan menjadi sangat penting dalam mendorong penanganan perkara anak melalui pendekatan restorative justice dan diversi. Perlindungan anak melalui perlakuan khusus tersebut diperlukan dengan mempertimbangkan kepentingan yang terbaik bagi anak, dimana anak adalah subyek dengan kebutuhan khusus dan berhak atas masa depannya.

Khususnya Bapas, melalui petugas Pembimbing Kemasyarakatan (PK), tidak hanya menjadi instansi yang diberikan tugas untuk melakukan penelitian kemasyarakatan berkaitan dengan anak yang terlibat dalam perkara pidana sebagaimana yang pernah diatur dalam UU Pengadilan Anak. Tetapi melalui UU SPPA ini, Bapas menjadi salah satu unsur penting dalam proses penyelesaian tindak pidana yang dilakukan atau melibatkan anak.

UU SPPA ini mengatur secara jelas dan tegas peran yang harus, bahkan pada beberapa peran mempunyai gradasi “wajib”, dijalankan oleh Bapas. Peran yang dijalankan oleh Bapas tersebut bergerak sejak tahap penyelidikan, penyidikan, hingga tahap pembimbingan, setelah menjalani pidana. Namun demikian, semangat yang terkandung dalam UU SPPA ini adalah dengan

Ibid. Hal. 8

Anjar Nawan, Konsep Diversi ..., ibid.

Achmad Ratomi, Penelitianyang Berjudul, Prosedur Pelaksanaan Diversi Pada Tahap Penyidikan Dalam

Penyelesaian Tindak Pidana Yang Dilakukan Oleh Anak. Fakultas Hukum Universitas Lambung Mangkurat, 2010 Hal. 4 
mengedepankan upaya pemulihan secara berkeadilan (Restoratif Justice) dan menghindarkan anak dari proses peradilan (Diversi). Oleh karena itu, Pasal 7 ayat (1) menyebutkan bahwa pada tingkat penyidikan, penuntutan, dan pemeriksaan perkara Anak di pengadilan negeri wajib diupayakan diversi. ${ }^{9}$

Bagaimanapun juga, kehadiran diversi dianggap sebagai langkah perlindungan terhadap anak, namun perlu juga dipahami, bahwa tidak semua jenis tindak pidana dapat dilakukan diversi. Diversi ini dilaksanakan dalam hal tindak pidana dilakukan dan diancam dengan pidana penjara di bawah 7(tujuh) tahun serta bukan merupakan pengulangan tindak pidana. ${ }^{10}$

Sedangkan, jika perkara anak harus masuk dalam proses peradilan, maka Bapas (dalam hal ini Pembimbing Kemasyarakatan) atau pendamping lain, sesuai dengan ketentuan peraturan perundang-undangan mempunyai kewajiban untuk memberikan pendampingan terhadap anak dalam setiap tingkat pemeriksaan (lihat Pasal 23 Ayat (1). ${ }^{11}$

Berdasarkan fenomena tersebut, Kota Surakarta merupakan salah satu daerah di Jawa Tengah dengan sistem peradilan pada anak yang terlibat tindak pidana telah menerapkan konsep diversi dan sistem peradilan restoratif. Sehingga Kota Surakarta merupakan salah satu kota layak anak yang dipilih Kementerian Negara Pemberdayaan Perempuan sejak tahun 2006.

Konsekuensinya, Pemkot Surakarta harus berupaya memberikan perlindungan khusus bagi anak-anak yang berkonflik dengan hukum salah satunya dengan membentuk tim kerja untuk penerapan restorative justice. Data tahanan anak di Rutan Kota Surakarta per 16 Juli 2009 menunjukkan angka 13. Artinya, terdapat 13 anak yang harus menghabiskan waktunya di dalam tahanan dengan fasilitas sangat terbatas, meskipun untuk kriminalitas ringan. Dari persoalan itu, makalah ini akan membahas mengenai tiga hal: (1) Bagaimana tugas dan wewenang BAPAS terkait dengan penanganan anak yang berhadapan dengan hukum di Kota Surakarta dalam sistem diversi dan restorative justice? (2) Kenapa diperlukannya kerjasama antara BAPAS dengan lembaga-lembaga terkait dalam penanganan anak yang berhadapan dengan hukum di Kota Surakarta dalam sistem diversi dan restorative justice? (3) Bagaimana membangun model kerjasama yang ideal antara BAPAS dengan lembaga-lembaga terkait di Kota Surakarta dalam sistem diversi dan restorative justice?

\section{Metode Penelitian}

Penelitian ini adalah penelitian deskriptif kualitatif yang berusaha menginventarisasi bahan hukum (mengumpulkan, mengelompokkan dan mengklarifikasi) dalam rangka meneliti konsistensi dan sinkronisasi penerapan peraturan perundang-undangan dengan kenyataannya di lapangan, mengenai penerapan konsep diversi serta Peraturan MA(Perma) Nomor 4 Tahun 2014 tentang Pedoman Pelaksanaan Diversi Dalam Sistem Peradilan Pidana Anak (UU SPPA), yang ditandatangani oleh Ketua MA Hatta Ali pada 24 Juli 2014. Perma ini dikeluarkan menyambut berlakunya UU No. 11 Tahun 2012 tentang Sistem Peradilan Pidana Anak (UU SPPA) yang mewajibkan para aparat Polisi, Jaksa, dan Pengadilan, untuk melakukan diversi dalam kasuskasus tindak pidana anak pada semua tahapan peradilan dengan melihat praktiknya di kota Surakarta. Serta dilihat pula sinkronisasinya dengan amanah Undang-Undang Dasar RI 1945, Undang-Undang RI No. 35 Tahun 2014 tentang Perubahan Atas Undang-Undang No. 23 Tahun 2002 tentang Perlindungan Anak, dan Undang-Undang No. 10 Tahun 2012 tentang Anak, serta melihat bagaimana diterapkannya Undang-Undang No. 12 Tahun 1995 tentang Pemasyarakatan, di BAPAS Kota Surakarta.

9 Afner Juwono, Bapas Dalam Perspektif Sistem Peradilan Pidana Anak, dalam http://afnerjuwono. com/2013/07/bapas-dalam-perspektif-sistem-peradilan.html, diakses tgl 16 Maret 2015 jam 15.15

10 Ibid.

11 Ibid. 


\section{Hasil Penelitian dan Pembahasan}

1. Tugas dan Wewenang BAPAS Terhadap ABH Pada Tahapan Penyidikan dan Penyelidikan di Kota Surakarta dalam Sistem Diversi dan Restorative Justice

Pelaksanaan sistem Pemasyarakatan mempunyai tujuan akhir yaitu terciptanya kemandirian warga binaan Pemasyarakatan atau membangun manusia mandiri. Sistem Peradilan pidana dalam kerangka sistem merupakan rangkaian kegiatan yang dilakukan dalam rangka menegakkan hukum pidana dan menjaga ketertiban sosial, dilaksanakan mulai kerja polisi dalam melakukan penyidikan peristiwa pidana, penuntutan oleh Jaksa Penuntut Umum, Pemeriksaan perkara di pengadilan dan pelaksanaan hukuman di Lapas, Rutan, dan Cabang Rutan. Seluruh rangkaian kegiatan tersebut harus saling dukung mendukung secara sinergis hingga tujuan dari bekerjanya sistem peradilan pidana tersebut dapat dicapai.

Salah satu kegiatan dalam rangkaian kegiatan sistem peradilan pidana tersebut dilaksanakan oleh Balai Pemasayrakatan (BAPAS) yang merupakan bagian dari kegiatan sub sistem pemasyarakatan narapidana atau sub-sub sistem peradilan pidana. Namun demikian, keberadaan dan peran Balai Pemasyarakatan (BAPAS) tersebut sering diabaikan atau bahkan tidak diketahui oleh sub sistem yang lain dalam sistem peradilan pidana. Keadaan pengabaian atau tidak diketahuinya Balai Pemasyarakatan (BAPAS) tersebut tentu saja mempengaruhi keberhasilan kegiatan sistem peradilan pidana secara keseluruhan. Dimana Balai Pemasyarakatan (BAPAS) merupakan bagian dari sistem Tata Peradilan, mempunyai tugas melaksanakan pembimbing dan mendampingi ABH dalam proses Peradilan Anak.

\section{a. Tugas BAPAS}

Rumusan dalam Undang-Undang No.12 Tahun 1995 Tentang Pemasyarakatan. Dalam Pasal 1 angka 4 tersebut di atas tentu saja belum memberikan kejelasan peran dari BAPAS. Penjabaran dari peran BAPAS tersebut dapat disimak pada Peraturan Pemerintahg No.31 Tahun 1999 Tentang Pembinaan dan Pembimbingan Warga Binaan Pemasyarakatan. Menurut Pasal 1 angka 6 Petugas Pemasyarakatan yang melaksanakan tugas pembimbingan klien pemasyarakatan disebut sebagai pembimbing Kemasyarakatan. Dengan demikian, tugasnya melakukan pembimbingan terhadap klien pemasyarakatan. ${ }^{12}$

Pembimbingan Kemasyarakatan (PK) merupakan jabatan teknis yang disandang oleh petugas pemasyarakatan di BAPAS dengan tugas pokok melaksanakan bimbingan dan penelitian terhadap warga binaan pemasyarakatan (WBP) sesuai Pasal 8 ayat 1 dan ayat 2 Undang-Undang RI No. 12 Tahun 1995 Tentang Pemasyarakatan. Sebagaimana diketahui, bahwa setiap anak yang berhadapan dengan hukum berhak untuk mendapatkan perlindungan baik fisik, mental, spiritual maupun sosial sesuai dengan prinsip-prinsip Konvensi Hak-Hak Anak dan Undang-Undang Perlindungan Anak yang meliputi nondiskriminasi, kepentingan yang terbaik untuk anak, hak untuk hidup, kelangsungan hidup dan perkembangan, dan penghargaan terhadap anak.

Berdasarkan prinsip tersebut, baik anak yang berhadapan dengan hukum, Balai Pemasyarakatan melalui Pembimbing Kemasyarakatan mempunyai kekuatan untuk menentukan keputusan yang terbaik bagi anak, melaui rekomendasi dalam Penelitian Kemasyarakatan maupun dalam pembimbingan. Dengan peran BAPAS yang dilakukan oleh Pembimbing Kemasyarakatan (PK) juga dapat ditemukan pada Undang-Undang No.3 Tahun 1997 tentang Pengadilan Anak, Bab IV Pasal 34 Ayat (1) yang menyatakan, bahwa Pembimbing Kemasyarakatan mempunyai tugas berikut ini. ${ }^{13}$

1) Membantu memperlancar tugas penyidik, penuntut umum, dan hakim dalam perkara anak nakal, baik di dalam maupun di luar sidang anak, dengan membuat laporan hasil penelitian kemasyarakatan (LITMAS). 
2) Membimbing, membantu, dan mengurus anak nakal berdasarkan putusan pengadilan yang menjatuhi pidana bersyarat, pidana pengawasan, pidana denda, diserahkan kepada negara dan harus mengikuti latihan kerja atau yang memperoleh pembebasan bersyarat dari Lembaga Pemasyarakatan.

\section{b. Wewenang BAPAS}

Hasil utama dari pelaksanaan tugas. Pembimbing Kemasyarakatan dalam perkara anak nakal adalah laporan hasil penelitian kemasyarakatan (Pasal 56 Ayat (1) UndangUndang No.3 Tahun 1997) yang berisi data individu anak, keluarga, pendidikan dan kehidupan sosial anak, dan kesimpulan data pendapat dari pembimbing kemasyarakatan. ${ }^{14}$ Manfaat dari laporan hasil penelitian kemasyarakatan tersebut sebagai salah satu bahan pertimbangan Hakim dalam memutuskan perkara anak. Dalam Pasal 59 Ayat (2), Hakim wajib mempertimbangkan laporan penelitian kemasyarakatan tersebut, karena dalam menentukan sanksi yang akan dijatuhkan kepada anak nakal, hakim mempunyai pilihan, yaitu menjatuhkan sanksi (Pasal 23) atau mengambil tindakan (Pasal 24).Secara teoritis, pilihan sanksi yang dapat dijatuhkan kepada anak adalah untuk mengambil keputusan yang terbaik untuk anak. Anak yang berkonflik dengan hukum secara sosiologis tidak dapat dinyatakan salah sendiri, karena belum menyadari akibat dari tindakannya dan belum dapat memilih mana tindakan yang baik dan tidak baik bagi dirinya maupun orang lain.

Pelanggaran pidana oleh anak lebih merupakan kegagalan proses sosialisasi dan lemahnya pengendalian sosial terhadap anak. Oleh karena itu keputusan hakim dalam perkara anak harus mempertimbangkan keadaan anak yang sesungguhnya atau realitas sosial anak tersebut, bukan hanya melihat aspek pidananya saja. Dikaitkan dengan UndangUndang No.23 Tahun 2002 tentang Perlindungan Anak, pada Pasal 16 dirumuskan, bahwa setiap anak berhak memperoleh perlindungan anatara lain penjatuhan hukuman yang tidak manusiawi dan penangkapan, penahanan atau penjatuhan pidana hanya dapat dilakukan sebagai upaya terakhir. ${ }^{15}$

\section{Pola Penanganan dan Peran BAPAS KOTA Surakarta Terhadap ABH}

BAPAS merupakan sebuah institusi yang berkaitan erat dengan sistem peradilan pidana yang melaksanakan penegakan hukum dengan memberikan pelayanan hukum kepada masyarakat tanpa mengabaikan nilai-nilai hak asasi manusia sebagai salah satu tugas yang harus dijalankan. Balai Pemasyarakatan merupakan salah satu unit pelaksana teknis yang menangani pembimbingan terhadap klien pemasyarakatan. Pembimbingan tersebut adalah terhadap klien anak maupun klien dewasa. Khusus untuk klien anak, diberikan perlakuan khusus dengan dilibatkannya petugas Pembimbing Kemasyarakatan (PK) dari Balai Pemasyarakatan dalam proses hukumnya, yaitu proses penyelidikan dan penyidikan, penuntutan, persidangan, pelaksanaan putusan/vonis hakim.

Berdasarkan data yang didapatkan dari Balai Pemasyarakatan Surakarta, diperoleh informasi bahwa peran Balai Pemasyarakatan dalam pembimbingan terhadap anak nakal dilakukan oleh petugas pembimbing kemasyarakatan (PK) dari Balai Pemasyarakatan yang mendampingi klien anak mulai dari penyidikan, penuntutan, persidangan, hingga pelaksanaan putusan hakim Pembimbing kemasyarakatan (PK) mempunyai peranan yang sangat strategis dalam penanganan terhadap $\mathrm{ABH}$. Hal ini terjadi karena pembimbing kemasyarakatan mempunyai 3 (tiga) peranan yang melekat dalam mata rantai proses penegakan hukum, yaitu: 


\section{a. Pra Ajudikasi}

Pra ajudikasi merupakan suatu tahap pada saat dimulainya proses penyidikan terhadap anak nakal oleh kepolisian. Dalam tahap ini pembimbing kemasyarakatan melaksanakan tugasnya untuk membuat laporan hasil penelitian kemasyarakatan (Litmas) atas pemintaan pihak penyidik kepolisian. Hasil laporan penelitian kemasyarakatan tersebut, nantinya juga bermanfaat untuk membantu jaksa dalam membuat tuntutan dan membantu hakim dalam membuat putusan terhadap ABH. Adapun pengertian Litmas (Case Study) adalah berikut ini. ${ }^{16}$

1) Untuk menentukan diagnosa, atau penilaian maupun untuk penentuan terapi, langkah apa setelah ada litmas sebagai hasil penelitian masalah sosial yang dihadapi klien, dan strategi tugas yang bagaimana, serta model-model pembinaan yang tepat bagi klien yang bersangkutan maupun tahanan, napi, dan anak didik.

2) Juga bermanfaat dalam pelaksanaan proses pemberian bantuan, atau dapat dikatakan sebagai proses intervensi, ikut campur dalam pemecahan masalah dan berguna untuk evaluasi.

\section{b. Ajudikasi}

Setelah laporan hasil penelitian kemasyarakatan (Litmas) selesai dibuat, maka diserahkan kepada pihak penyidik dari kepolisian yang selanjutnya diberkaskan guna dilimpahkan kepada Jaksa Penuntut Umum di Pengadilan Negeri. Apabila Jaksa Penuntut Umum telah selesai melakukan pemeriksaan kepada anak nakal, maka selanjutnya didaftarkan untuk proses persidangan di pengadilan hingga turunnya penetapan sidang. Dalam setiap proses sidang di pengadilan, anak nakal atau klien anak wajib didampingi oleh pembimbing kemasyarakatan (PK), sebagaimana diatur dalam Pasal 55 UndangUndang Nomor 3 Tahun 1997 tentang Pengadilan Anak, yang berbunyi bahwa "Dalam perkara Anak Nakal sebagaimana dimaksud dalam Pasal 1 angka 2, Penuntut Umum, Penasihat Hukum, Pembimbing Kemasyarakatan, orang tua, wali atau orang tua asuh dan saksi wajib hadir dalam sidang".

Dalam Pasal 59 Ayat (2) Undang-Undang Nomor 3 Tahun 1997 tentang Pengadilan Anak, menyebutkan bahwa, "Putusan sebagaimana dimaksud dalam ayat (1) wajib mempertimbangkan laporan Penelitian Kemasyarakatan dari Pembimbing Kemasyarakatan.” Dari bunyi Pasal tersebut, jelas tertulis pentingnya peran Laporan Penelitian Kemasyarakatan (Litmas) dari Pembimbing Kemasyarakatan (PK) dalam menentukan putusan hakim terhadap perkara anak nakal. Bahkan, laporan penelitian kemasyarakatan tersebut bersifat mutlak, karena pengertian kata "wajib" dalam penjelasannya dikatakan, bahwa apabila ketentuan tersebut tidak dipenuhi, maka berakibat pada batalnya putusan hakim demi hukum.

\section{c. Post Ajudikasi}

Apabila ABH atau klien anak telah dijatuhi putusan atau vonis oleh hakim, maka pembimbing kemasyarakatan masih mempunyai tugas untuk membimbing, membantu, dan mengawasi anak nakal atau klien anak tersebut sebagaimana diatur dalam Pasal 34 Ayat (1) huruf b Undang-Undang Nomor 3 Tahun 1997 tentang Pengadilan Anak yang berbunyi:

"Membimbing, membantu, dan mengawasi ABH yang berdasarkan putusan pengadilan dijatuhi pidana bersyarat, pidana pengawasan, pidana denda, diserahkan kepada negara dan harus mengikuti latihan kerja, atau anak yang memperoleh pembebasan bersyarat dari

16 CM Marianti Soewandi. Buku Materi Kuliah Akademi Ilmu Pemasyarakatan, Bimbingan dan Penyuluhan Klien. Jakarta: Sekretariat Jenderal Departemen Kehakiman dan Hak Asasi Manusia Republik Indonesia. 2003. Hal. 74 
Lembaga Pemasyarakatan.”

Berdasarkan Petunjuk Pelaksanaan Menteri Kehakiman Republik Indonesia Nomor E-39-PR.05.03 Tahun 1987 tentang Bimbingan Klien Pemasyarakatan, bimbingan klien dilaksanakan melalui tiga tahap berdasarkan kebutuhan dan permasalahan klien yang meliputi beberapa hal berikut.

1) Bimbingan tahap awal, yang terdiri dari:

a) Penelitian Kemasyarakatan.

b) Menyusun rencana program bimbingan.

c) Pelaksanaan program bimbingan.

d) Penilaian pelaksanaan program tahap awal dan penyusunan rencana bimbingan tahap lanjutan.

2) Bimbingan tahap lanjutan, yang terdiri dari:

a) Pelaksanaan program bimbingan.

b) Penilaian pelaksanaan program tahap lanjutan dan penyusunan rencana bimbingan tahap akhir.

3) Bimbingan tahap akhir, yang terdiri dari:

a) Pelaksanaan program bimbingan.

b) Meneliti dan menilai keseluruhan hasil pelaksanaan program bimbingan.

c) Mempersiapkan klien untuk menghadapi akhir masa bimbingan dan mempertimbangkan kemungkinan pelayanan bimbingan tambahan (after care).

d) Mempersiapkan surat keterangan akhir masa bimbingan klien; dan

e) Mengakhiri masa bimbingan klien dengan diwawancarai oleh Kepala Balai Pemasyarakatan.

Dalam melaksanakan peran-peran profesionalnya dari tahap pra ajudikasi, ajudikasi, hingga post ajudikasi, pembimbing kemasyarakatan menjalankan beberapa peran profesional yang spesifik, antara lain berikut ini. ${ }^{17}$

1) Sebagai peneliti, yaitu mencari informasi, data, dan fakta dengan menggunakan metode dan teknik penelitian untuk menghasilkan laporan yang baik, berkualitas, dan objektif. Selanjutnya melakukan analisa-analisa yang cerdas, tepat, dan akurat, guna menghasilkan saran dan rekomendasi yang kuat dan rasional.

2) Sebagai broker, yaitu membantu menyediakan pelayanan sosial kepada anak nakal atau klien anak yang sangat membutuhkan solusi terbaik bagi diri anak nakal atau klien anak tersebut, karena setiap perbuatan yang dilakukannya terdapat latar belakang yang menjadi sebab dilakukannya.

3) Sebagai mediator, diharapkan dapat menjadi penghubung antara klien anak dengan berbagai sumber pelayanan sosial yang ada dalam masyarakat.

4) Public educator, yaitu memberikan dan menyebarkan informasi mengenai masalah dan pelayanan-pelayanan sosial yang tersedia.

5) Advocate, merupakan bentuk memberikan wawasan atau pengetahuan mengenai hak-hak yang layak diperjuangkan oleh klien anak dalam memperoleh pelayanan sehingga lembaga yang melayaninya lebih responsif untuk memenuhi kebutuhan atau hak-hak klien anak.

6) Behaviour specialist, yaitu seorang pembimbing kemasyarakatan dapat menjadi ahli yang dapat melakukan berbagai strategi dan teknik perubahan perilaku melalui pola pikir sehingga tercipta suatu keyakinan pada diri klien anak.

17 Retno Siti Sari. "Peran Balai Pemasyarakatan Dalam Proses Peradilan Anak Menurut Undang-Undang Nomor 3 Tahun 1997 Di Surakarta”. Makalah, disusun Sebagai Syarat Untuk Mengikuti Diklat DIM Tingkat IV Departemen Hukum Dan Hak Asasi Manusia Republik Indonesia, 2006, Hal. 59 
7) Konsultan, adalah memberikan nasihat dan saran kepada klien anak mengenai berbagai cara pemenuhan kebutuhan dan pemecahan suatu permasalahan yang terjadi tanpa menimbulkan masalah baru.

8) Konselor, yaitu memberikan pelayanan konseling kepada klien anak sesuai profesi pembimbing kemasyarakatan secara profesional.

\section{Membangun model kerjasama yang ideal antara BAPAS dengan lembaga-lembaga terkait di Kota Surakarta dalam sistem diversi dan restorative justice}

Proses hukum bagi para pelaku tindak pidana yang dilakukan oleh anak di bawah umur dengan tetap memperhatikan masa depan 'si anak' merupakan suatu langkah dalam menanggulangi tindak pidana yang dilakukan anak di kemudian hari. Dimana proses hukum tersebut harus berjalan secara efisien demi tercapainya suatu penegakkan hukum yang diharapkan oleh seluruh lapisan masyarakat khususnya bagi $\mathrm{ABH}$ dan keluarganya. Langkah penanggulangan yang menjadi acuan masyarakat beserta pemerintah dan para penegak hukum dalam menanggulangi tindak pidana yang dilakukan oleh anak, antara lain berikut.

Pertama, dukungan dari masyarakat sangat dibutuhkan dalam pengungkapan kasus kejahatan khususnya kasus tindak pidana yang dilakukan oleh anak, apabila tindak pidana dilakukan oleh anak terjadi di lingkungan sekitar, maka pihak masyarakat yang mengetahui adanya tindak pidana tersebut segera mengadukan hal tersebut ke aparat keamanan setempat dengan tetap memperhatikah psikologis dan masa depan anak. Hal tersebut sangat dibutuhkan dalam upaya menanggulangi tindak pidana yang dilakukan oleh anak, sebab terkadang tindak pidana yang dilakukan oleh anak, pada level masyarakat tidak jarang diperlakukan sama dengan tindak pidana yang dilakukan oleh orang dewasa. Peran masyarakatlah khususnya pihak keluarga ABH yang sangat dibutuhkan dalam menjaga psikis 'si anak' ketika berhadapan dengan hukum.

Kedua, Kepolisian sebagai penyidik dan sekaligus pelindung, pengayom, dan pelayanan masyarakat khususnya dalam hal menghadapi $\mathrm{ABH}$, harus teliti dan cermat menangani psikis anak dengan model introgasi yang 'tidak mengintimidasi' $\mathrm{ABH}$, agar $\mathrm{ABH}$ tidak mengalami trauma yang mendalam. Untuk itu, kinerja, profesionalisme maupun mentalitas dari pihak kepolisian sangat diharapkan dalam mengungkap kejahatan khususnya kasus-kasus tindak pidana yang dilakukan oleh anak.

Ketiga, "Penuntut umum adalah jaksa yang diberikan wewenang oleh undang-undang untuk melakukan penuntutan dan melaksanakan penetapan hakim" 18 sesuai dengan pasal 13 Kitab Undang-undang Hukum Acara Pidana (KUHAP). Kejaksaan merupakan suatu institusi yang diberikan wewenang untuk melakukan penuntutan terhadap $\mathrm{ABH}$, yang mana jaksa diharapkan untuk dapat mencermati, menelaah dan memperhatikan unsur-unsur pasal yang disangkakan terhadap $\mathrm{ABH}$ diharapkan dapat memperhatikan masa depan $\mathrm{ABH}$.

Keempat, Pihak kehakiman harus bekerja efisen dalam menjatuhkan hukuman yang benarbenar mempertimbangkan masa depan $\mathrm{ABH}$ sebelum menjatuhkan putusan hukum. Kelima, lembaga independen dan lembaga swadaya masyarakat yang berkaitan dengan masalah perlindungan anak, dapat melakukan upaya penanggulangan jika terjadi proses 'intimidasi' terhadap anak dalam proses di tiap tingkatan hukum yang dilaluinya, yaitu dengan cara mengedepankan hak-hak seorang anak seperti melindungi anak yang berhadapan dengan hukum, mendampingi, memantau, melakukan pendekatan pada anak yang menjadi pelaku tindak pidana, hal ini berguna untuk membantu upaya untuk memulihkan dan menjaga psikis anak yang melakukan tindak pidana.

Dari rincian yang telah diketengahkan sebelumnya, merupakan suatu langkah-langkah yang bertujuan untuk menanggulangi serta menjaga psikis $\mathrm{ABH}$, yang bagaimanapun juga

18 Soerjano Soekanto, 2008, Kitab Undang-undang Hukum Pidana, Acara Pidana, Dan Perdata, Cet. 1, (Jakarta : Visimedia), Pasal 13 KUHAP 
merupakan 'aset masa depan bangsa', yang terbagi atas beberapa langkah, yaitu langkah pencegahan dan langkah untuk menanggulangi jika terjadi tindak pidana yang dilakukan oleh anak di bawah umur yang dapat dilakukan oleh keluarga, masyarakat beserta lembaga-lembaga terkait.

\section{Penutup}

Berdasarkan hasil kajian yang telah dijabarkan pada bab-bab sebelumnya, maka penulis dapat memberikan beberapa simpulan berikut.

1. Pembimbing kemasyarakatan (PK) yang dibentuk oleh BAPAS Surakarta, mempunyai peranan yang sangat strategis dalam penanganan terhadap $\mathrm{ABH}$. Hal ini terjadi karena pembimbing kemasyarakatan mempunyai 3 (tiga) peranan yang melekat dalam mata rantai proses penegakan hukum, yaitu Pra Ajudikasi, Ajudikasi, dan Post Ajudikasi

2. BAPAS Kota Surakarta melalui Pembimbing Kemasyarakatan (PK), melaksanakan fungsinya sejak tersangka anak ditangkap oleh polisi dan dibuatkan berita acara pemeriksaan, hingga setelah terdakwa anak diputuskan oleh hakim, dan PK selalu dilibatkan oleh kepolisian, serta PK melakukan penelitian guna menyusun laporan penelitian kemasyarakatan (litmas).

3. Menjalankan secara konsisten Pasal. 7 dan Pasal. 8 UU No. 11 Tahun 2012 tentang Sistem Peradilan Pidana Anak. Agar terjadi sinergisitas antar aparatur hukum dalam mengatasi $\mathrm{ABH}$, dengan tujuan terlaksananya pemulihan psikis, keamanan, perlindungan terhadap masa depan anak, tidak mendapatkan perlakuan diskriminatif dari masyarakat, dan anak mendapatkan keadilan restorative.

\section{Daftar Pustaka}

Adi, Koesno,2009, Kebijakan Kriminal dalam Sistem Peradilan Pidana yang Berorientasi pada Kepentingan Terbaik Bagi Anak, Pidato Pengukuhan Jabatan Guru Besar dalam bidang Ilmu Hukum Pada Fakultas Hukum Universitas Brawijaya Malang.

Juwono, Afner, Bapas Dalam Perspektif Sistem Peradilan Pidana Anak, http://afnerjuwono. com/2013/07/bapas-dalam-perspektif-sistem-peradilan.html, diakses tgl 16 Maret 2015 jam 15.15

Martina, Efektifkah Konsep Diversi dan Keadilan Restoratif pada Sistem Peradilan Anak di Indonesia?, dalam http://hukum.kompasiana.com/2012/08/21/efektifkah-konsep-diversidan-keadilan-restoratif-pada-sistem-peradilan-anak-di-indonesia-487685.html, diakses tgl 20 November 2014 jam 15.15

Nawan, Anjar, Konsep Diversi dan Restoratif Justice, dalam https://www.anjarnawanyep.com/ konsep-diversi-dan-restorative-justice/, diakses tgl 20 November 2014 jam 15.15

Ratomi, Achmad, 2010, Prosedur Pelaksanaan Diversi Pada Tahap Penyidikan Dalam Penyelesaian Tindak Pidana Yang Dilakukan Oleh Anak, Fakultas Hukum Universitas Lambung Mangkurat.

Sari, Retno Siti, 2006, "Peran Balai Pemasyarakatan Dalam Proses Peradilan Anak Menurut Undang-Undang Nomor 3 Tahun 1997 Di Surakarta”, Makalah, disusun Sebagai Syarat Untuk Mengikuti Diklat DIM Tingkat IV Departemen Hukum Dan Hak Asasi Manusia Republik Indonesia.

Soekanto, Soerjano, 2008, Kitab Undang-undang Hukum Pidana, Acara Pidana, Dan Perdata , Cet. 1, (Jakarta : Visimedia). 
Soewandi, CM Marianti, 2003, Buku Materi Kuliah Akademi Ilmu Pemasyarakatan, Bimbingan dan Penyuluhan Klien. Jakarta: Sekretariat Jenderal Departemen Kehakiman dan Hak Asasi Manusia Republik Indonesia. 